\title{
Komunikasi CSR Program CSR Rumah Srikandi PT Sari Husada Yogyakarta Kepada Stakeholder
}

\author{
Oleh: Aswad Ishak dan Adhianty Nurjanah \\ Prodi Ilmu Komunikasi Universitas Muhammadiyah Yogyakarta \\ ishak@umy.ac.id
}

\begin{abstract}
Abstrak
Penelitian komunikasi corporate social responsibility (CSR) public relations kepada stakeholder PT Sari Husada Yogyakarta bertujuan untuk mengetahui bagaimanakah aktivitas yang dilakukan public relations dalam mengkomunikasikan program corporate social responsibility (CSR) PT Sari Husada Yogyakarta kepada stakeholder internal dan eksternal. Obyek penelitian ini adalah program corporate social responsibility (CSR) PT Sari Husada Yogyakarta. Penelitian ini menggunakan metode studi kasus yang memberikan gambaran secara mendetail tentang latarbelakang, sifat-sifat serta karakter yang khas dari kasus yang diteliti yakni bagaimana aktivitas yang dilakukan public relations dalam mengkomunikasikan program corporate social responsibility (CSR) kepada stakeholders internal dan eksternal PT Sari Husada Yogyakarta.

Hasil yang diperoleh, PT Sari Husada melaksanakan program CSR Rumah Srikandi dengan melakukan kerjasama dengan PKPU Yogyakarta untuk pengelolaannya. Komunikasi kegiatan CSR dilakukan dengan mengandalkan media sosial berbasis online yang ditunjang oleh siaran pers untuk media massa dan pembuatan buletin. Kegiatan komunikasi yang telah dilakukan belum menunjukkan efektifitasnya karena persoalan sumberdaya manusia pengelolanya yang belum memadai dari sisi kemampuannya.
\end{abstract}

Kata kunci: Komunikasi, public relations, corporate social responsibility (CSR), stakeholde.

\section{A. Latar Belakang}

Secara esensi corporate social responsibility (CSR) merupakan wujud dari giving back dari korporat kepada stakeholders. Hal ini dapat dilakukan dengan cara melakukan dan menghasilkan bisnis berdasar pada niat tulus guna memberi kontribusi yang paling positif pada stakeholders. Dengan demikian, corporate social responsibility (CSR) itu seharusnya bukan merupakan kegiatan sosial yang sedehana saja, melainkan program perusahaan yang memperhatikan kepentingan para stakeholders yang terkait baik stakeholders internal maupun stakeholders ekternal, serta lingkungan dimana perusahaan itu beroperasi. Hal ini sejalan seperti yang disampaikan Beth Stephens (dalam Fajar, 2010: 96) yang mengatakan, bahwa mencari keuntungan bukanlah satu-satunya tujuan perusahaan, namun hanya sebagai bisnis utamanya. Selebihnya perusahaan harus memperhatikan kepentingan sosial dan lingkungan sebagai bagian dari tujuan perusahaan. Hal ini didasarkan pada dua alasan yaitu: (1) dampak negatif dari operasional perusahaan dan (2) hubungan antara perusahaan dengan masyarakat. Untuk itu perusahaan saat ini 
dituntut untuk melakukan tanggung jawab sosial kepada masyarakat yang biasa dikenal dengan corporate social responsibility (CSR).

Di Indonesia pelaksanaan corporate social responsibility (CSR) telah diatur secara tegas dalam Undang-Undang Nomor 25 tahun 2007 tentang penanaman modal dan Undangundang Nomor 40 tahun 2007 tentang Perseroan terbatas. Dalam pasal 15 huruf b

UU Nomor 25 Tahun 2007 tentang Penanaman Modal menyebutkan "Setiap penanam modal berkewajiban melaksanakan tanggung jawab sosial perusahaan". Dan pada pasal 1 angka 3 UU Nomor 40 Tahun 2007 tentang Perseroan Terbatas menyebutkan "Tanggung jawab sosial dan Lingkungan adalah komitmen Perseroan untuk berperan serta dalam pembangunan ekonomi berkelanjutan guna meningkatkan kualitas kehidupan dan lingkungan yang bermanfaat, baik bagi bagi Perseroan sendiri, komunitas setempat, maupun masyarakat pada umumnya (Fajar, 2010: 1). Dengan adanya peraturan tersebut setiap perusahaan memiliki kewajiban untuk melaksanakan suatu bentuk tanggung jawab sosialnya kepada masyarakat dan lingkungan. Terlebih bagi perusahaan yang memanfaatkan sumber daya alam dalam kegiatan bisnisnya dengan wilayah operasi bisnis yang berada di lingkungan masyarakat.

Dalam program Corporate Social Responsibility (CSR) mengkomunikasikan aktifitas CSR kepada stakeholdersnya baik internal maupun eksternal merupakan salah satu tahapan penting dalam keseluruhan implementasi program corporate social responsibility (CSR). Upaya pengkomunikasian program corporate social responsibility (CSR) dalam perusahaan merupakan aktivitas yang dilakukan oleh public relations perusahaan. DeFleur dan Dennis (1998) mendefinisikan public relations sebagai proses komunikasi dimana individu atau unit-unit masyarakat berupaya untuk menjalin relasi yang terorganisasi dengan berbagai kelompok atau publik untuk tujuan tertentu (Iriantara, 2004:5). Dengan demikian dalam konteks public relations mengkomunikasikan program corporate social responsibility (CSR) kepada stakeholdersnya merupakan hal penting yang harus dilakukan dan sangat bermanfaat bagi perusahaan.

Mengkomunikasikan program Corporate Social Responsibility (CSR) akan memberi manfaat kepada perbaikan citra perusahaan dan idealnya dapat memberikan akses kepada publik untuk dapat melakukan verifikasi dan memberikan masukan atau kritik bagi pengembangan program ke depan (Wilcox, 2006; Tanaya 2004). Selain itu upaya komunikasi yang dilakukan public relations kepada stakeholdersnya dengan menggunakan komunikasi dialogis antara perusahaan dengan stakeholders dapat mengurangi terjadinya konflik kepentingan dalam pelaksanaan program corporate social responsibility (CSR). Dengan menggunakan komunikasi dialogis yang bersifat dua arah, maka program CSR akan didukung dan bermanfaat bagi seluruh pemangku kepentingan baik internal maupun eksternal perusahaan. Hal ini dikarenakan dalam membuat program CSR tidak hanya berdasarkan pada apa yang diinginkan perusahaan melainkan juga mendengarkan apa yang menjadi kebutuhan dan harapan stakeholdernya.

Salah satu perusahaan yang terus berkomitmen untuk mengkomunikasikan program Corporate Social Responsibility (CSR) nya kepada seluruh stakeholders baik internal maupun eksternal adalah PT. Sari Husada Yogyakarta. PT Sari Husada adalah perusahaan yang memproduksi berbagai jenis produk bernutrisi untuk ibu dan anak-anak Indonesia dengan harga terjangkau dan standar internasional. Perusahaan ini didirikan pada 
Diterbitkan oleh Fakultas Sastra dan Budaya

Universitas Ahmad Dahlan Yogyakarta

tahun 1954 dengan nama NV Saridele, sebagai perwujudan program kecukupan protein nasional yang diselenggarakan Pemerintah Indonesia bekerja sama dengan Perserikatan Bangsa-Bangsa (PBB). PT Sari Husada mengembangkan dan memproduksi susu anak SGM, yang hingga kini dikenal dan banyak digunakan masyarakat luas. (dalam http://www.sarihusada.co.id/ina/home/ diakses pada tanggal 29 Desember 2013 pukul $20.00 \mathrm{Wib}$.

\section{B. Corporate Social Responsibility (CSR) dan Peran PR dalam Komunikasi}

Terdapat banyak definisi yang dikemukakan beberapa ahli mengenai pengertian dari corporate sosial responsibility (CSR), salah satu diantaranya menurut Putri Suhandari (dalam Untung, 2009: 1) definisi dari CSR adalah komitmen perusahaan atau dunia bisnis untuk berkontribusi dalam pengembangan ekonomi yang berkelanjutan dengan memperhatikan tanggung jawab sosial perusahaan dan menitikberatkan pada keseimbangan antara perhatian terhadap aspek ekonomis, sosial dan lingkungan.

Definisi yang lebih spesifik diungkapkan oleh The World Business Council for Sustainable Development (WBCSD) yang merupakan lembaga internasional beranggotakan 120 perusahaan multinasional dari 30 negara dunia. WBCSD mendefinisikan CSR: "CSR is the continuing commitment by business to behave ethically and contributed to economic development while improving the quality of live of the workforce and their families as well as of the local community and society at large" (dalam

Prayogo, 2011: 75).

Definisi tersebut mengungkapkan bahwa CSR adalah "Komitmen berkelanjutan dunia usaha untuk berperilaku etis, memberikan kontribusi bagi pembangunan ekonomi yang sekaligus memperbaiki kualitas hidup angakatan kerja dan keluarganya serta komunitas lokal dan masyarakat secara keseluruhan (Iriantara, 2004:49).

Definisi lainnya tentang CSR dalam Tanaya (2004:44) menyatakan tanggungjawab sosial perusahaan mencakup "kumpulan kebijakan dan praktek yang berhubungan dengan stakeholders, nilai-nilai, pemenuhan ketentuan hukum, penghargaan dengan stakeholders, pemenuhan ketentuan hukum, penghargaan masyarakat dan lingkungan serta komitmen badan usaha untuk berkontribusi dalam pembangunan berkelanjutan." CSR bukan hanya kegiatan yang bersifat karikatif perusahaan. Bila dilihat dari aktivitas kegiatan CSR mencakup proteksi lingkungan, jaminan kerja, hak asasi manusia, keterlibatan dalam komunitas, standar bisnis, pasar, pengembangan ekonomi dan badan usaha, proteksi kesehatan, pengembangan kepemimpinan dan pendidikan hingga bantuan kemanusiaan. (Tanaya, 2004).

Dalam melaksanakan kegiatan CSR perusahaan ini public relations memiliki peranan yang cukup penting yang tidak dapat dikesampingkan. Peran public relations menurut Cutlip, Center \& Broom (2006) membagi peran PR menjadi empat perannya sebagai berikut: 1) Teknisi Komunikasi, dimana PR hanya melakukan tugas-tugas teknis tanpa terlibat dalam pendefinisian masalah dan pemilihan solusi di tingkat manajemen; 2) Expert prescriber, PR mengambil peran sebagai ahli dalam hal ini manajemen memberikan otoritas untuk memberikan solusi kepada perusahaan, namun PR terpisah dari aktivitas 
perusahaan; 3) Fasilitator komunikasi, dimana PR berperan sebagai pendengar dan perantara komunikasi antar manajemen dengan publiknya; 4) Fasilitator pemecah masalah, PR berperan mendefinisikan dan memecahkan masalah disini PR dilibatkan dalam pembuatan keputusan manajemen.

Selain keempat peranan yang ada tersebut, PR juga memiliki model penerapan dalam melaksanakan tugas dan fungsinya. Dalam pandangan James Grunig (1992:285) terdapat 4 model praktek komunikasi PR: yaitu 1) Model Publicity atau Press Agentry model ini PR melakukan propaganda atau kampanye melalui proses komunikasi satu arah (one way process) untuk tujuan publisitas yang menguntungkan secara sepihak, khususnya menghadapi media massa dan dengan mengabaikan kebenaran informasi sebagai upaya menutupi (manipulasi) unsur-unsur negatif dari suatu organisasi; 2) Model Public Information, PR bertindak seolah-olah sebagai journalist in resident. Berupaya membangun kepercayaan organisasi melalui proses komunikasi satu arah dan tidak mementingkan persuasif. Seolah bertindak sebagai wartawan dalam menyebarluaskan publisitas informasi dan berita ke publik, dalam hal ini unsur kebenaran dan objektivitas diperhatikan. 3) Model Two Way Assimetrical, pada model ini PR menyampaikan pesan dengan komunikasi dua arah dan berdasrkan riset serta menggunakan strategi komunikasi persuasive. Unsur kebenaran diperhatikan untuk membujuk publik. Kekuatan membangun hubungan dan pengambilan inisiatif didominasi PR. 4) Model Two Way Symetrical, model komunikasi dua arah yang berimbang. Model ini mampu memecahkan dan menghindari konflik dengan memperbaiki pemahaman publik untuk membangun saling pengertian dukungan dan mengungkan bagi keduabelah pihak.

\section{Public Relations dan Komunikasi kepada Stakeholder}

Aktivitas PR selalu berhubungan dengan publik atau yang sering disebut sebagai stakeholder. Stakeholder atau lazim disebut sebagai pemangku kepentingan merupakan merupakan setiap kelompok yang berada di dalam maupun di luar perusahaan yang mempunyai peran dalam menentukan keberhasilan perusahaan. Menurut Freeman (1984) mendefinisikan stakeholder sebagai any group or individual who can affect or is affected by the achievement of the firm's objectives, organization's success depend on creating real dialogue with its diverse stakeholders, rather than trying to manipulate them.

Stakeholder bisa dikategorikan menjadi dua yaitu 1) Stakeholder internal adalah mereka yang berada dalam lingkungan organisasi terdiri dari karyawan, manajemen, pemegang saham (investor), keluarga karyawan. 2) Stakeholder eksternal adalah mereka yang berada di luar lingkungan organisasi terdiri dari pemerintah, pelanggan, pemasok, bank, komunitas dan pers. Teori stakeholder (Lawrence, Weber, Post, 2005:5) menyatakan bahwa perusahaan melayani kepentingan publik yang lebih luas untuk menciptakan nilai dalam masyarakat. Teori ini berpendapat bahwa perusahaan memiliki banyak kewajiban dan seluruh kepentingan stakeholder harus diperhatikan. "Terciptanya hubungan baik antar stakeholder baik internal maupun eksternal stakeholder merupakan nilai tersendiri bagi perusahaan".

Untuk memberikan informasi yang mendalam kepada seluruh stakeholder yang ada, maka PR harus mengkomunkasikan kegiatan yang telah dilakukan. Termasuk dalam 
Diterbitkan oleh Fakultas Sastra dan Budaya

Universitas Ahmad Dahlan Yogyakarta

hal ini kegiatan CSR yang telah dirancang dan dilaksanakan perlu disampaikan kepada publik. Hal ini agar publik dapat mengetahui dan memahami bagaimana perusahaan melaksanakan tanggungjwabnya dalam menyelesaiakan masalah sosial yang ada di masyarakat. Dalam mengkomunikasikan program CSR kepada seluruh stakeholder perusahaan Freeman (2007) menyarankan agar PR perusahaan meninggalkan cara lama agar berhasil dalam membangun hubungan dengan pemangku kepentingan (stakeholder). Menurut Freeman (dalam Jalal, 2008) terdapat lima hal yang merupakan pilar komunikasi berkelanjutan.

Pertama, penyatuan keberlanjutan dalam model bisnis. Dalam hal ini keberlanjutan yang dimaksud adalah keseimbangan antara tujuan ekonomi, sosial dan lingkungan. Jadi keberlanjutan sebagai tujuan bisnis dan ekonomi hanya menjadi salahsatu saja dan bukan pula yang terpenting. Kedua, menyangkut berbagai cara untuk memastikan bahwa tujuan keberlanjutan itu memang diterapkan dalam cara-cara turunanya: operasi perusahaan dari hari ke hari.

Ketiga, terkait dengan karyawan yang menurut Freeman harus diikutsertakan dan diberdayakan. Keberlanjutan perusahaan melalui CSR sangat bergantung kepada pekerjanya yang percaya pada tujuan tersebut. Komunikasi keberlanjutan pertama-tama harus dilakukan kepada pekerja, baru kepada stakeholder eksternal. Hal ini akan membuat seluruh pekerja menjadi duta keberlanjutan yang dipercaya oleh pihak-pihak eksternal yang berhubungan dengan mereka.

Keempat, menekankan pada pentingnya keuntungan nyata yang dirasakan oleh para pemangku kepentingan setempat. Jika perusahaan tidak dapat membuktikan bahwa dengan paradigma keberlanjutan maka seluruh pemangku kepentingan setempat mendapatkan keuntungan, maka sulit gagasan keberlanjutan itu dikomunikasikan. Pada akhirnya keberlanjutan itu tidak akan mendapatkan dukungan luas. Dengan demikian sangat penting bagi perusahaan untuk membuktikan bahwa keberlanjutan memang menguntungkan semua pihak (stakeholder) perusahaan.

Kelima adalah memaksimumkan hubungan dengan pemangku kepentingan. Dalam hal ini yang sangat ditekankan adalah bahwa hubungan tersebut bersifat saling menguntungkan.

\section{Masalah dan Tujuan Penelitian}

Perumusan masalah dalam penelitian ini adalah bagaimana komunikasi CSR public relations dalam mengkomunikasikan program corporate social responsibility (CSR) kepada stakeholders internal dan eksternal PT Sari Husada Yogyakarta. Adapun tujuan penelitian ini adalah untuk mengetahui bagaimana public relations dalam mengkomunikasikan program corporate social responsibility (CSR) kepada stakeholder internal dan eksternal PT Sari Husada Yogyakarta?

\section{E. Metode Penelitian}

Penelitian ini termasuk kedalam jenis penelitian deskriptif kualitatif. Penelitian deskriptif menurut Whitney (dalam Nazir, 1988: 63) yaitu penelitian untuk pencarian fakta dengan interpretasi yang tepat. Penelitian ini menggunakan metode studi kasus, metode 
studi kasus adalah memberikan gambaran secara mendetail tentang latar belakang, sifatsifat serta karakter yang khas dari kasus, dari sifat-sifat khas tersebut akan dijadikan suatu hal yang bersifat umum. (Nazir, 1988:66). Data dikumpulkan melalui interview (wawancara) dan dokumentasi perusahaan. Data dalam penelitian ini akan dianalisis secara kualitatif dengan langkah-langkah: pengumpulan data, reduksi data, penyajian serta pembahasan dan menarik kesimpulan. Teknik yang dilakukan dalam uji validitas data yaitu dengan teknik triangulasi. Menurut Moleong (2001: 178), triangulasi adalah teknik pemeriksaan keabsahan data yang memanfaatkan sesuatu lain diluar data itu untuk keperluan pengecekan atau sebagai pembanding terhadap data itu. Teknik triangulasi sumber dipergunakan dalam penelitian yang dilakukan ini.

\section{F. Pembahasan}

\section{Pentingnya Kegiatan CSR PT Sari Husada Yogyakarta}

Sebagai salah satu perusahaan yang ternama di bidang makanan dan kesehatan PT Sari Husada Yogyakarta memiliki peran yang cukup penting dalam perkembangan masyarakat. Kegiatan operasional perusahaan dilakukan dengan memperhatikan segala aspek manajemen organisasi untuk menghasilkan produk yang berkualitas. Tidak hanya menghasilkan produk, namun kegiatan perusahaan juga memperhatikan pada kondisi masyarakat sekitar. Hal ini sebagai bentuk hubungan baik antara PT Sari Husada Yogyakarta dengan masyarakat sebagai salah satu stakeholder eksternal. Perusahaan memperhatikan kondisi masyarakat dan turut berperan aktif dalam membantu menyelesaikan persoalan yang ada secara nyata di tengah kehidupan sosial. Hal ini menandai bahwa PT Sari Husada Yogyakarta melakukan kegiatan tanggung jawab sosialnya kepada masyarakat. Hal ini seperti yang disampaikan oleh Endah Prasetyoningtyas selaku public relations officer PT Sari Husada pada wawancara tanggal 19 September 2014:

"Sebenarnya CSR sendiri itu kan tanggung jawab perusahaan kepada masyarakat walupun kegiatan perusahan tidak mulai ketika peraturan itu keluar, tapi sudah dilakukan dari awal pendirian nya sarihuda untuk mengatasi kekurangan gizi, peningkatan gizi ataupun kualitas hidup."

Dari apa yang disampaikan Endah Prasetyoningtyas tersebut secara jelas menyatakan bahwa kegiatan mengenai CSR yang dilakukan oleh PT Sari Husada bukan sekedar kegiatan yang dipaksakan oleh aturan formal berupa perundangan yang berlaku. Namun kegiatan CSR yang dilakukan sudah mendahului dilaksanakan sebelum peraturan yang ada terkait dengan CSR dikeluarkan oleh pemerintah. Aktifitas CSR yang dilakukan ini sudah menjadi kebijakan penting perusahaan untuk melakukan kebajikan untuk stakeholdernya. Hal ini menandakan bahwa kegiatan CSR sudah menjadi kesadaran awal oleh pihak manajemen sejak kelahiran dan kehadiran perusahaan tersebut di tengahtengah masyarakat.

Kegiatan CSR yang dilakukan oleh PT Sari Husada merupakan aktifitas yang tidak jauh dari bidang operasional perusahaannya. Oleh karena PT Sari Husada menghasilkan 
Diterbitkan oleh Fakultas Sastra dan Budaya

Universitas Ahmad Dahlan Yogyakarta

produk makanan kategori kesehatan antara berupa susu formula, maka aktifitas CSR yang dibangun juga yang terkait dengan aspek kesehatan masyarakat. Tentu saja hal ini lebih mudah dilakukan karena masih berada pada area yang sama dengan core bisnis utama yang dijalankannya. Kondisi akan lebih mudah dalam melakukan pekerjaan CSR dan saling mendukung dengan lini bisnisnya.

Guna mendukung kegiatan CSR ini maka perusahaan mengalokasikan anggaran secara khusus. Dalam hal ini bagian public relations melakukan rancangan kegiatan CSR yang akan dilakukan yang kemudian diajukan kepada pihak manajemen perusahaan untuk mendapatkan persetujuannya.

"Kita membuat desain program dulu beserta bugetnya, lalu kita ajukan kepada pihak manajemen kemudian nanti manajemen yang akan mengapprove. Ketika mereka tidak menstujui, maka tidak akan dijalani. Tapi kalau step-step program itukan pastikan ada lagi." (wawancara, Endah Prasetyoningtyas, public relations officer Sari Husada, 19 September 2014)

Kegiatan CSR yang dilakukan oleh PT Sari Husada dengan menggandeng pihak lain yang berkompeten untuk dapat melaksanakan kegiatan. PT Sari Husada melakukan kerjasama dengan PKPU sebuah NGO yang bergerak di bidang penyaluran bantuan sosial dan sejenisnya untuk mengelola kegiatan CSR Rumah Srikandi pada tahapan selanjutnya setelah mendapatkan persetujuan programnya oleh manajemen perusahaan. Pelibatan lembaga diluar perusahaan untuk terlibat aktif dalam pengelolaan kegiatan CSR ini menjadi keunikan tersendiri, mengingat banyak perusahaan lain yang menerapkan pola lain melalui pengelolaan langsung oleh manajemen internalnya sendiri. Hal ini bisa dipahami dengan adanya perbedaan kepentingan dan ketersediaan sumberdaya yang dimiliki oleh setiap perusahaan. Keterlibatan NGO diluar perusahaan sebagai cerminan kuatnya hubungan antara perusahaan, masyarakat dan juga pemerintah. Business, government, and society are interdependent and their relationship is complex in every nation (Post, et.al., 1999:25). Dengan demikian kegiatan CSR merupakan bagian penting dari problematika sosial yang terjadi di tengah masyarakat. CSR sudah menjadi suatu kebutuhan bagi organisasi bahkan dapat dipandang menjadi sebuah strategi bisnis yang harus dilaksanakan oleh perusahaan.

Kegiatan CSR yang dilakukan PT Sari Husada adalah manifestasi dari keterkaitan perusahaan dengan stakeholdernya. Perusahaan memberikan manfaat kepada stakeholder tidak hanya dari sisi produk yang dihasilkan. Lebih jauh kebijakan perusahaan yang dihasilkan dapat dirasakan oleh masyarakat sekitarnya lebih meluas lagi dalam kahidupan sehari-hari.

\section{Komunikasi CSR PT Sari Husada Yogyakarta kepada Stakeholder}

Rumah Srikandi merupakan sebuah program corporate social responsibility (CSR) dari PT Sari Husada Generasi Mahardika Yogyakarta yang bekerja sama dengan Lembaga Kemanusian Nasional PKPU Yogyakarta. Program CSR Rumah Srikandi ini ditujukan untuk memberikan peningkatan kualitas hidup masyarakat di kampung Badran Yogyakarta yang mejunjung tiga pilar yaitu kesehatan, pendidikan, dan ekonomi masyarakat. Ketiga pilar kegiatan ini diyakini dapat memberikan manfaat yang besar kepada masyarakat. Besarnya manfaat yang bisa diterima dan dirasakan oleh masyarakat 
belum tentu akan diketahui oleh semua lapisan masayarakat. Perusahaan harus melakukan serangkaian kegiatan lain untuk dapat menyebarluaskan informasi yang relevan terkait persoalan CSR yang dijalankannya. Hal ini merupakan sebagai bentuk upaya keterbukaan dan akuntabilitas perusahaan. Oleh sebab itu perusahaan perlu melakukan mengkomunikasikan kegiatan CSR yang telah dilaksanakan tersebut kepada stakeholder terkait.

Menurut Akhta Suhendra selaku kepala bidang pendayagunaan PKPU Yogyakarta mengatakan bahwa melakukan program CSR merupakan suatu hal yang penting bagi sebuah perusahaan, sebagai tanggung jawab sosial kepada mayarakat.

"Selain adanya undang-undang, kalau kita berbicara tentang CSR itu merupakan sebuah tanggung sosial dari sebuah perusahaan. Untuk mengatasi permasalahan di masyarakat dan itu juga merupakan hal yang penting ketika perusahaan memberikan keuntungan kepada masyarakat untuk mengkomunikasikan perusahaan itu sendiri". (Wawancara Kepala Bidang Pendayagunaan PKPU Yogyakarta Akhta Suhendra, Tanggal 7 Juli 2014).

Selain sebagai bentuk pelaksanaan tanggung jawab sosialnya kepada masyarakat, kegiatan CSR juga perlu untuk dikomunikasikan. Hal ini agar masyarakat dapat benarbenar mengetahui apa dan bagaimana perusahaan tersebut dalam menjalankan kegiatan operasionalnya. Sehingga aktifitas pengkomunikasian kepada stakeholder baik internal maupun eksternal merupakan hal yang penting untuk dilakukan. Hal ini ditujukan selain untuk memberikan informasi tentang kegiatan yang dilakukan sebuah perusahaan, juga untuk memberikan pemahaman serta membentuk opini yang positif stakeholder terhadap kebedaan dan operasional perusahaan terkait permasalahan-permasalahan yang muncul. Oleh karena itu PT Sari Husada Generasi Mahardika Yogyakarta sebagai suatu perusahaan besar yang cukup banyak memiliki stakeholder melalui PKPU Yogyakarta sangat memerlukan aktivitas mengkomunikasikan tentang program CSR Rumah Srikandi sebagai bentuk keterbukaan perusahaan kepada stakeholder. Pada program Rumah Srikandi ini stakeholder yang terlibat adalah PT Sari Husada Generasi Mahardika, PKPU, Pemerintah dan masyarakat pada umumnya.

Sementara itu, menurut Akhta Suhendra misi yang paling penting dalam pengkomunikasian program CSR Rumah Srikandi ini adalah diharapkan para perusahaan atau corporate dapat mencontoh program tersebut, mengingat saat ini para perusahaan dalam menjalankan program CSR hanya sekali jalan saja tanpa adanya tindakan lebih lanjut. Keberlanjutan program ini menjadi hal yang langka ditemukan dalam praktek CSR yang berlangsung.

"Kalau untuk mengkomunikasikan itu sangat penting, karena ini sebagai keterbukaan perusahaan terkait dengan program yang dilaksanakan. Selain itu misi yang lebih penting adalah bagaimana dari program ini dapat di duplikasi dan replikasi oleh perusahaan-perusahaan. Mohon maaf saat ini perusahaanperusahaan menjalankan program CSR hanya sekali habis." (Wawancara, Akhta Suhendra Kepala Bidang Pendayagunaan PKPU Yogyakarta, 7 Juli 2014). 
Diterbitkan oleh Fakultas Sastra dan Budaya

Universitas Ahmad Dahlan Yogyakarta

Dalam pelaksanaan program CSR Rumah Srikandi ini, pihak PKPU Yogyakarta sebagai CSR organizer dari CSR Rumah Srikandi PT Sari Husada Generasi Mahardika Yogyakarta, membentuk tiga divisi antara lain adalah project manager, project officer, dan subag officer. Namun dalam hal ini yang memiliki tugas dan peran untuk mengkomunikasikan adalah divisi project officer baik mengkomunikasikan kepada pemangku kepentingan di internal maupun eksternal.

Aktivitas komunikasi Program Rumah Srikandi yang telah dijalankan dalam prakteknya cenderung fokus pada penggunaan media massa seperti melalui press release, news letter, peliputan media TV, website, dan digital social media. Hal tersebut seperti yang disampaikan Akhta Suhendra selaku Kepala Bidang Pendayagunaan PKPU Yogyakarta:

"Untuk pelaksanaan kita membagi tiga yaitu ada project manager, project officer, dan subag officer. Disini yang menjalankan komunikasi adalah temanteman dari project officer, selain mengkomunikasikan ke masyarakat juga keluar. Untuk pengkomunikasian kita biasanya melalui press release, news letter, peliputan media TV, website dan sosial media." (Wawancara Kepala Bidang Pendayagunaan PKPU Yogyakarta Akhta Suhendra, Tanggal 7 Juli 2014).

Kegiatan pengkomunikasian Program Rumah Srikandi yang dilakukan oleh PKU lebih kepada stakeholder eksternal dari PT Sari Husada. Untuk stakeholder internal maka dilakukan secara langsung oleh public relations officer PT Sari Husada. Media komunikasi yang dipergunakan juga berbeda jika dibandingkan dengan komunikasi kepada para pemagku kepentingan eksternal.

"Kalau internal kita lebih ke newsletter kepada karyawan, dan email blast. Kalau ke eksternal kita malah ngajak kepada wartawan-wartawan ketika ada event tertentu atau pun membuat berita mengenai kegiatan-kegiatan terus kita berikan kepada media-media. Kalau bulletin kita partnernya dengan PKPU Yogyakarta. Jadi selain dari kita yang mengkomunikasikan, PKPU juga ikut mengkomunikasikan. Seperti buat bulettin kemarin." (wawancara, Endah Prasetyoningtyas, public relations officer PT Sari Husada, 19 September 2014)

Dengan demikian, maka ada pihak yang melaksanakan kegiatan komunikasi untuk seluruh pemangku kepentingan yang ada. Berdasarkan hasil wawancara yang dilakukan dapat disimpulkan bahwasannya aktivitas pengkomunikasian program CSR Rumah Srikandi kepada stakeholders baik internal maupun eksternal selama ini lebih kepada menggunakan teknik komunikasi satu arah (one way communications). Mengacu pada temuan data yang ada tersebut maka aspek komunikasi yang dijalankan oleh public relations officer PT Sari Husada dan juga oleh PKPU Yogyakarta untuk program Rumah Srikandi mengambil bentuk peran teknis (Cutlip at.al., 2006). Peran teknis ini lebih menekankan pada aspek penyampaian informasi melalui pembuatan media komunikasi dan mendistribusikan kepada semua pihak yang terkait dan terlibat dalam sasaran program. Aspek manajerial belum tampak dilaksanakan. Hal ini dapat terjadi oleh karena keberdaan public relations officer sebagai penanggung jawab utama program CSR Rumah Srikandi 
kemungkinan berada tidak pada level top manajemen. Sekaligus PKPU Yogyakarta hanya sebagai organizer atau tim teknis pelaksana program CSR tersebut. Sehingga aktifitas dalam kerangka penyusunan kebijakan strategisnya belum terlalu terlihat.

Namun disisi lain terdapat sebuah harapan dan keinginan dari pengkomunikasian program CSR Rumah Srikandi ini untuk menggunakan teknik komunikasi dua arah.

"Sebetulnya kami ingin sekali mengadakan workshop yang akan ditujukan kepada stakeholder dan korporasi terkait dengan CSR. Dengan target kita ingin mengedukasi terkait dengan program CSR." (Wawancara Kepala Bidang Pendayagunaan PKPU Yogyakarta Akhta Suhendra, Tanggal 7 Juli 2014).

Hal ini menjelaskan sebuah peluang bagi berlangsungnya kegiatan komunikasi yang sifatnya dialogis untuk program-program selanjutnya di masa yang akan datang. Peluang ini sekaligus dapan menjadikan tantangan baru untuk PT Sari Husada dan PKPU Yogyakarta dalam merancang kegiatan CSR maupun komunikasinya kepada seluruh pemangku kepentingan yang ada. Pada sisi yang lain apabila kegiatan komunikasi dapat mengambil bentuk pada model dua arah yang di dalamnya terjadi interaksi yang terjadi maka antara perusahaan dengan stakeholdernya akan dapat melakukan proses adaptasi satu dengan yang lainnya. Sehingga harapannya perubahan pada kedua belah pihak akan dapat saling menguntungkan. Dengan demikian pandangan Grunig (1992) mengenai penerapan model komunikasi dua arah yang sifatnya simetris dapat terjadi. Bagaimanapun juga apabila ini yang dilakukan oleh perusahaan maka penerimaan pemangku kepentingan atas posisi dan keberadaan perusahaan atas produk atau jasa beserta kebijakan yang menyertainya akan dapat terjadi. Perusahaan dapat semakin kokoh posisinya, citranya semakin baik dan bahkan menuju pada reputasi yang baik dengan menunjukkan tanggung jawab sosialnya.

\section{Dampak Komunikasi CSR PT Sari Husada yang Dihasilkan}

Kegiatan komunikasi yang dilakukan oleh PT Sari Husada dan PKPU Yogyakarta tentunya ditujukan untuk menyampaikan perkembangan yang ada seputar pelaksanaan Program Rumah Srikandi dan hasil yang dapat dicapai dan dirasakan oleh penerima manfaat. Komunikasi program yang dilaksanakan tersebut dengan intensitas yang masih rendah

\footnotetext{
"Ada beberapa cara bisa lewat bulletin, kita buat berita kemudian kita berikan kepada media-media. Untuk intensitasnya paling tidak dua sampai tiga kali dalam setahun, tidak terlalu sering juga. Kalau website juga kita ada di NGO nya juga ada tapi tidak khusus mengenai masalah ini." (Wawancara, Endah Prasetyoningtyas, public relations officer PT Sari Husada, 19 September 2014)
}

Kondisi ini dapat menimbulkan potensi stakeholder tidak dapat mengetahui perkembangan secara lebih cepat. Keterlambatan informasi yangs sampai ke tangan pemangku kepentingan ini dapat berpotensi menyebabkan kesalahan penilaian yang dilakukan. Apabila dalam setahun hanya dua atau tiga kali komuniksi dilaksanakan maka masyarakat sudah akan dijejali dengan berbagai macam informasi lain yang mungkin akan 
Diterbitkan oleh Fakultas Sastra dan Budaya

Universitas Ahmad Dahlan Yogyakarta

berbeda dengan kondisi faktual yang terjadi. Hal senada juga disampaikan Akhta Suhendra bahwa aktivitas komunikasi yang telah dilakukan dengan menggunakan mediamedia tersebut dirasakan belum cukup efektif. Hal ini dikarena adanya suatu keterbatasan dari sisi SDM terkait dengan pola komunikasi yang dilakukan. Meskipun adanya keterbatasan tersebut, menurut Akhta Suhendra, ternyata media online seperti website, sosial media (facebook, twitter) merupakan suatu media yang paling efektif digunakan dalam mengkomunikasikan program CSR Rumah Srikandi.

"Media yang paling efektif itu biasanya kita menggunakan sosial media seperti facebook, twitter. Dan juga kita punya website yang dapat digunakan untuk mengkomunikasikan kepada stakeholders dengan mencantumkan press release. (Wawancara Kepala Bidang Pendayagunaan PKPU Yogyakarta Akhta Suhendra, Tanggal 7 Juli 2014).

Kecanggihan media internet baik melalui sosial media maupun website dalam melakukan aktivitas komunikasi memang tidak dapat dipungkri lagi. Mengingat media internet tersebut dapat menjangkau khalayak yang sangat luas dan tanpa batas dengan waktu yang sesingkat mungkin. Hal itu juga yang menjadi alasan PT Sari Husada Generasi Mahardika Yogyakarta dan pihak PKPU Yogyakarta untuk menggunakan media internet selain komunikasi yang cepat dan biaya yang murah, juga dikarenakan saat ini banyak kalangan masyarakat yang mencari informasi lebih menggunakan media internet.

Berkaitan dengan aktivitas pengkomunikasian program CSR Rumah Srikandi, tentu saja tidak terlepas dari hal-hal yang dapat menjadi suatu faktor penghambat dalam kegiatan tersebut. Menurut Akhta Suhendra faktor penghambat tersebut lebih kepada internal SDM, dimana terdapat suatu keterbatasan pada keilmuan dari anggota tim dalam melakukan aktivitas pengkomunikasian sekaligus sebagai teknik komunikasi itu sendiri. Sehingga hal itu juga yang dapat menjadikan ketidak efektifan dari kegiatan komunikasi yang dibangun.

"Faktor penghambat lebih kepada temen-temen dituntut untuk berpikir ke eksternal. karena kita tidak punya orang yang benar-benar khusus untuk dijadikan media information. Dan juga keterbatasan keilmuan teman-teman sehingga hal itu juga yang membuat tidak efektif." (Wawancara Kepala Bidang

Pendayagunaan PKPU Yogyakarta Akhta Suhendra, Tanggal 7 Juli 2014).

Selain hal tersebut, ada hal lain yang harus diperhatikan untuk dapat mencapai dampak yang diharapkan dari proses komunikasi yang berlangsung. Pemetaan sumberdaya dan kebiasaan konsumsi media oleh para pemaangku kepentingan dalam mencari sumber informasi harus diperhatikan. Sehingga penggunaan semua saluran komunikasi yang ditetapkan harapannya dapat memberikan kesesuaian dengan dampak yang akan dicapai.

Meskipun terdapat suatu faktor penghambat dari kemampuan SDM yang ada tersebut, Akhta Suhendra memandang bahwa adanya hubungan yang baik khsusunya kepada media merupakan suatu hal yang dapat menjadi faktor pendukung dalam aktivitas pengkomunikasian program CSR Rumah Srikandi. Karena dengan adanya mitra hubungan tersebut dapat mempermudah untuk melakukan aktivitas komunikasi kepada stakeholder 
internal dan eksternal. Selain itu, untuk menunjang tingkat ke efektifan dari aktivitas komunikasi, kegiatan evaluasi ataupun media monitoring juga dilakukan oleh pihak PKPU Yogyakarta. Guna mengetahui keefektifan media yang digunakan dan seberapa besar tingkat penerbitan press release di media surat kabar harian. Monitoring media komunikasi ini dilakukan untuk media konvensional dan media online.

Merujuk pada pendapat Freeman (2007) dalam Jalal (2008) yang menekankan pada pentingnya keuntungan nyata yang dirasakan oleh para pemangku kepentingan setempat. Jika perusahaan tidak dapat membuktikan bahwa dengan paradigma keberlanjutan maka seluruh pemangku kepentingan setempat mendapatkan keuntungan, maka sulit gagasan keberlanjutan itu dikomunikasikan. Pada akhirnya keberlanjutan itu tidak akan mendapatkan dukungan luas. Dengan demikian sangat penting bagi perusahaan untuk membuktikan bahwa keberlanjutan memang menguntungkan semua pihak (stakeholder) perusahaan. Dampak inilah yang diharapkan oleh setiap perusahaan yang melakukan kegiatan CSR dan komunikasi CSR yang dibangun. PT Sari Husada telah berupaya melakukan kegiatan komunikasi untuk menyampaikan informasi terkait dengan Program Rumah Srikandi yang dijalankan.

\section{G. Penutup}

\section{Kesimpulan}

Melalui pemaparan dan pembahasan data yang dilakukan, maka dapat diperoleh kesimpulan sebagai berikut:

1. Program Rumah Srikandi yang digagas oleh PT. Sari Husada merupakan kegiatan CSR yang melibatkan masyarakat di Kampung Badran Yogyakarta yang berfokus pada pilar kesehatan sesuai dengan produk yang dihasilkan dari lini utama bisnisnya. Pelaksanaan program CSR ini melibatkan PKPU Yogyakarta untuk menangani kegiatan operasional dan komunikasinya

2. Kegiatan komunikasi yang dilakukan oleh public relations PT Sari Husada dan PKPU Yogyakarta dilakukan pada stakeholder internal dan eksternal yang menggunakan media cetak berupa buletin dan publisitas melalui siaran pers di media massa serta penyampain melalui jejaring sosial berbasis online.

3. Komunikasi yang dijalankan belum memberikan dampak pengetahuan informasi secara meluas kepada seluruh stakeholder terkait. Kendala yang dihadapi karena persoalan kemampuan teknis SDM untuk menggunakan media komunikasi yang ada serta intensitas penerbitan informasi melalui media komunkasi yang masih rendah

4. Peran teknisi komunikasi lebih dominan dilakukan dalam kegiatan komunikasi Program CSR Rumah Srikandi kepada stakeholder. Penerapan model dua arah yang simetris juga belum terlihat dilakukan.

\section{Saran}

Dari pembahasan dan kesimpulan yang ada tersebut maka saran yang diusulkan:

1. Program CSR Rumah Srikandi dapat dilanjutkan dengan variasi program lainnya untuk menjamin keberlanjutan dan kemanfaatan bagi masyarakat yang berimbas 
Diterbitkan oleh Fakultas Sastra dan Budaya

Universitas Ahmad Dahlan Yogyakarta

bagi perusahaan sendiri.

2. Peningkatan intensitas penggunaan media komunikasi diikuti dengan anggaran yang lebih besar dan kemampuan SDM melakukan pengelolalan media komunikasi melalui pelatihan yang releva.

3. Penelitian selanjutnya dapat mencoba melihat bagaimana dampak dan tanggapan masyarakat penerima manfaat program CSR yang dilakukan oleh perusahaan.

\section{Referensi}

Pustaka:

Cutlip, Scoot M. Center, Allen H \& Broom, Glen M. (2000). Effektive Public Relations. Penerjemah Ch Renete Pohan. Edisi kedelapan. Jakarta: Indeks

Fajar, Mukti (2010). Tanggung Jawab Sosial Perusahaan di Indonesia: Studi tentang penerapan ketentuan CSR pada perusahaan multi nasional, swasta nasional \& BUMN di Indonesia. Yogyakarta: Pustaka Pelajar

Iriantara, Yosal (2004). Community Relations. Konsep dan Aplikasinya: Bandung Simbiosa Rekatama Media

Jalal. Komunikasi Keberlanjutan, Kehumasan Gaya Baru diakses dari http://www.csrindonesia.com/data/resensi/20080319100029-resdoc.pdf

Post, James E., Lawrance, Anne T., dan Weber, James (1999). Business and Society: Corporate Strategy, Public Policy, Ethics, 9 edition, USA: Irwin McGraw-Hill

Untung, Hendrik Budi. (2009). Corporate social responsibility. Jakarta: Sinar Grafika

Tanaya, Jimmy (2004). Tanggung Jawab Sosial Korporasi. Surakarta: The Business Watch Indonesia

Moleong J, Lexy (2001). Metodologi Penelitian Kualitatif. Bandung: Remaja Rosdakarya Nazir, Moh. (1988). Metode Penelitian. Jakarta: Ghalia Indonesia

Wawancara:

Akhta Sehendra, Project Manager Rumah Srikandi, PKPU Yogyakarta

Endah Prasetyoningtyas, Public Relations Officer PT Sari Husada Yogyakarta 
